\title{
Reflecting on Micro Finance in Poverty Reduction
}

\author{
Prof DY Dzansi \\ Mr VY Atiase \\ Department of Business Support studies, Faculty of Management Sciences, Central \\ University of Technology, Free State, South Africa. \\ Email: ddzansi@cut.ac.za
}

\section{Doi:10.5901/mjss.2014.v5n21p345}

\section{Abstract}

\begin{abstract}
Development policy has increasingly shifted towards expanding financial services to the poorer sections of the population following the Grameen Bank success. In spite of this and other micro finance success stories, the effectiveness of microfinance in reducing poverty continues to be questioned with some arguing that micro finance programmes have little to no impact on poverty reduction. Whilst demanding empirical evidence of positive impact, critics of microfinance as poverty reduction instrument continue to ask lingering questions like who is the programme supposed to reach? Who is it reaching? What impact is it making on the lives of the poor? On the other hand, some are steadfast that a well-designed microfinance programme can change the lives of the poor at the individual, household, enterprise and community levels and help raise the standard of living of the poor out of the poverty. In this study, the researchers enter the debate by reviewing both empirical and normative literature to determine the extent to which microfinance is able to reduce poverty. Based on insights gained, it is concluded that micro finance is not fulfilling its original mandate of extricating the poor from poverty or vulnerability to it to the level of comfort. We also provide recommendation for policy and practice.
\end{abstract}

Keywords: micro finance; poverty alleviation; micro finance institutions; MFIs; NGOs

\section{Introduction}

Poverty alleviation is a major if not the most important problem facing the world today. Since its inception and the success of the Grameen banks initiative in Bangladesh, micro finance has given hope that a lasting solution could be at hand. So profound is the belief that micro finance could be the magic wand to solve the world's seemingly unsolvable problem of poverty that global campaigns to raise awareness of the micro finance sector, and inspire nations to fund and encourage micro finance goals took place including the 1997 Microcredit Summit, where nearly 3,000 delegates from 137 nations agreed to set a goal of reaching 100 million of the poorest of the poor with credit for self-employment, and other financial services by 2005 (Quaraishi, 2005). The year 2005 was subsequently recognized as the UN International Year of Micro finance (Quaraishi, 2005).

However, in spite of its initial promise, the effectiveness of micro finance in reducing poverty is increasingly being questioned with growing advocacy for evidence of positive impact. Not surprisingly Mehdi and Schwank (2011) observed "the honeymoon with micro finance is over". They also stated: "time to reassess the limits and strengths of small-scale lending has come". Even whilst a number of researches have proven that micro finance programmes have little to no impact on poverty reduction (Morduch, 1998; Harper \& Arora, 2005), expectation still persists that, a well-designed micro finance programme can substantially change the lives of the poor at the individual, household, enterprise and community levels and help raise the poor out of poverty (Hume \& Mosley 1996; Morduch, 1999; Vanroose \& D'espallier, 2009). In order to validate the efficacy of micro finance in performing the poverty alleviation role questions such as who is the programme supposed to reach? Who is it reaching? What is micro finance achieving as far as women empowerment is concerned and many others needs to be answered. In this study, the researchers enter the debate by reviewing both empirical and normative literature to determine the extent to which micro finance is able to reduce poverty. The case of Ghana as well as a few others were evaluated to draw conclusion on micro finance's ability to fulfilling its mandate of extricating the poor from poverty or vulnerability to it to the level of comfort. 


\section{Objectives of the Study}

The main objective of this study was to conduct a review of the empirical and normative literature on micro finance programmes aimed at reducing poverty to determine the extent to which micro finance is performing its intended poverty alleviation role. This main objective was pursued through: determining who micro finance is supposed to reach; who micro finance is reaching; and what micro finance is achieving as far as women empowerment is concerned. Before examining these issues, the next section outlines the research methodology applied.

\section{Research Methodology}

In this study, the researchers adopted the world view that "people's knowledge, views, understandings, interpretations, experiences, and interactions constitute meaningful properties of social reality" (Mason, 2007). That is, social reality is subjective and can be captured through ones interpretation of the views, understandings, and experiences of others. Thus, it is possible to determine the extent to which micro finance is performing its intended poverty alleviation role by reviewing the knowledge that other researchers have accumulated on the subject and then use own interpretation and judgement to arrive at conclusions. This philosophical approach is termed interpretivism - a position that implied a qualitative research design - the collection of qualitative data and data analysis that does not involve numerical methods. Specifically, desk research was conducted by reviewing the literature leading to conclusions and recommendations. The next section provides a summary of the literature review.

\section{Literature Review}

The literature review is arranged to address the above subsidiary objectives in a systematic manner without implying any order of importance. The review starts with exploration of the meaning of the key concept micro finance. Thereafter, the nature of micro finance clients are explored. Following this, the importance of micro finance that deliberately targets the poor is dealt with. Thereafter, the use of micro finance for women empowerment is discussed. These four aspects are meant to identify the intended recipients of micro finance meant for poverty alleviation as well as who micro finance is currently reaching. The literature review continues with examination of the impact of micro finance on poverty globally and Ghana specifically. These two aspects are meant to find out the efficacy of micro finance in dealing with poverty. Finally, problems encountered in assessing the impact of micro finance is discussed.

\subsection{Defining Micro Finance}

The idea of providing financial assistance to the poor is not new. It dates as far back as 1950 where third world development strategies emphasized the need to provide working capital to the poor (Bakhoum et al. 1989). The term micro finance has therefore come to be associated with providing financial services to the poor to achieve poverty reduction (UNDP, 2004). It means the provision of a range of financial services to the poor in an effort to reduce their poverty (Vanroose \& D'espallier, 2009). Such financial services may include loans, savings, payment services, money transfers, insurance of their micro enterprises and households (Asian Development Bank [ADB], 2000; Vanroose \& D'espallier, 2009).

The above are all what micro finance means as far as this study is concerned. As a result, micro finance is operationally defined as the provision of financial services such as loans; savings; payment services; money transfers; insurance of micro enterprises; and households and individuals who can be classified as poor in an effort to reduce poverty. This means that from our viewpoint, micro finance should target the poor.

\subsection{Demarcating Micro Finance Clients}

In order for micro finance to adequately serve its purpose of reducing poverty, Micro Finance Institutions (MFIs) need criteria or strategy which can confidently be used in identifying the poor whilst excluding the non-poor.

The most common criterion that is used in identifying the poor is based on consumption and income levels. A person is considered poor if his or her consumption or income a day is below the nationally defined poverty line. Further people belonging to the bottom fifty percent of a country's nationally defined poverty line are considered as the very poor (Aguilar, 2006).

International standard poverty measures such as that of the World Bank (2001) is useful in identifying the poor and 
the very poor. With this criterion, people living on less than $\$ 1$ a day are considered the poorest and those that consume less than $\$ 2$ a day are classified to be poor - that is, are living below the poverty line. Most micro finance clients fall around or just below the poverty line (Helmes, 2006; Greely, 2005).

Besides income and consumption, other dimensions such as access to education, health, housing, vulnerability, social exclusion and access to social capital are very important in targeting the poor and the poorest (Aguilar, 2006).

Typically, micro finance clients are low-income persons that do not have access to formal financial institutions. They are mostly self-employed, home-based entrepreneurs, farmers, and petty traders. The nature of clients in urban areas is more diverse and includes service providers, petty traders, and artisans. The categories of micro finance clients are shown below.

Figures 1: Categories of Micro finance Clients

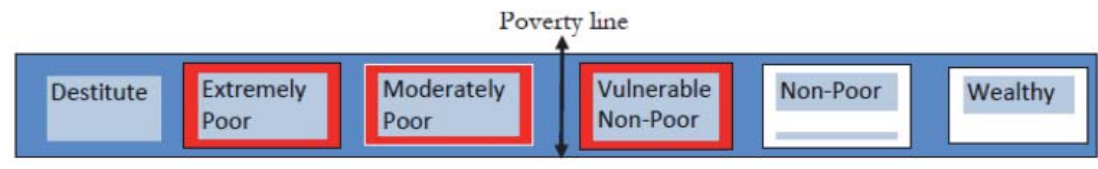

Source: (Helmes, 2006:20)

Most micro finance clients come from vulnerable non-poor and moderate poor categories and micro finance programmes that have a clear agenda and strategy of targeting the poorest of communities have most of their clients coming from the extreme poor (Helms, 2006).

\section{The Need for Micro Finance that Targets the Poor}

The main reason for extending micro finance to or tailoring micro finance services for the poor is not farfetched. In developing countries, the poor are eliminated from having access to meaningful financial service and therefore their participation in economic services is limited (Schneider, 1997; ADB, 2000). The exclusion ranges from partial in developed countries to total in least developed countries (Brau \& Woller, 2004).

Exclusion from access to financial services has therefore made the poor incapable of dealing with both financial and household shocks (Helmes, 2006). This means that the poor will not be able to access capital to start a business or re-invest into existing one. Not having access to finance also limits one's ability to living a quality life.

But as pointed out by Copestake et al. (2005) and Johnson and Rogaly (1997), micro finance institutions have the agenda of alleviating poverty. The idea is that, access to micro finance services enables the poor to improve their consumption, build equity over time, and improve their earning capacity which finally leads to an overall improvement in quality of life (ADB 2000).

According to Fischer (2005), what makes micro finance appealing is that it offers "hope to many poor people of improving their own situations through their own efforts". From this perspective it is easy to understand why micro finance is considered a critical instrument for poverty reduction.

\section{Micro Finance for Poverty Reduction through Women Empowerment}

Empowerment has been explained to mean different things. For example empowerment of women is viewed as the achievement of the well-being of women and the reduction and ultimate removal of gender inequality, both economically and socially (Quaraishi, 2005). However, the concept seems to generally refer to the process of increasing the capacity of individuals or groups to make choices and to transfer those choices into desired actions and outcomes (Krishna, 2003).

Women empowerment has three different dimensions namely improvement in income generation activities of women, increased physical wellbeing of women and their household and change in social and political status of women in taking leadership roles both at home and in the community (Mayoux, 2000).

For Quaraishi (2005), microcredit programs that focus on women is particularly welcome because women and particularly those in rural agrarian societies typically lack the collateral, literacy, and freedom of mobility necessary to compete for credit from conventional institutional sources. The author further argues that women are also found to spend disproportionately more of their incomes on household welfare than men and typically exhibit higher repayment and lower default rates. Thus extending credit to women will likely have beneficial outcomes for all household members, poor 
communities, and lenders themselves (Quaraishi, 2005).

According to Vanroose and D'espallier (2009), several studies have shown that access to micro finance contributes to women's empowerment including higher levels of mobility, political participation and decision-making. Among others, the millennium development goal seeks to ensure gender equality, the empowerment of women, bridging the gender disparity that currently exist (Littlefield et.al, 2003). Not surprisingly a sizeable number of NGOs, governments and other humanitarian institutions have advocated for micro finance programmes that promote gender policies (Mayoux, 2000; Cheston \& Kuhn, 2002). Some micro finance programmes focus their attention on women clients since women are believed to the form greater part of poor people who need financial services and are also believed to have good repayment behaviour (Fernando, 2006). Micro finance can therefore be a powerful instrument to achieving women empowerment and for that matter poverty reduction.

In most developing countries, women are marginalised in important life spheres such as education, employment and training. Their role is mostly reduced to family raising and child bearing which has denied them of the opportunity to develop themselves to earn incomes comparable to men. Therefore financial interventions combined with social intermediaries that are focused on women can help build women's human assets (skills, knowledge, self-esteem, bargaining power and control over household decisions) and social assets such as social networks, relationships of trust and access to wider institutions of society (Cohen \& Sebstad, 1999). Also, it has been observed that women are more likely than men to invest increased income into the wellbeing of the household and therefore empowering women financially can have a trickled down effect on the household as well as the community at large (Littlefield et al. 2003).

\section{Assessing the Impact of Micro Finance}

Impact assessment generally, is aimed at measuring the effect of a development project on the intended beneficiaries (Afrane, 2002). Impact assessments in micro finance has the objective of measuring outcomes of micro finance interventions but not merely assessing inputs and outputs (Hulme, 1997). Impact assessment in micro finance is the measurement of the effect of micro finance services on the poor. Conventionally, repeat borrowing and high repayment rates are thought to be signs of a good micro finance programme. However, these signs fail to answer basic questions of the positive effect of such programmes and who those programmes are actually reaching (Mayoux, 2001).

When the poor participate in a credit programme the expectation is that, overtime, such a person would be positively affected by the programme to the extent that transformation in terms of poverty reduction should take place in all aspects of the person's life. Such a transformation should happen at the individual, household and the enterprise levels (Mayoux, 2001). Impact assessment in micro finance therefore aims at evaluating by 'how much' and 'for whom' poverty has been alleviated or whether poverty is rather increased by the micro finance programme (Johnson \& Rogaly, 1997).

Assessing the impact of micro finance services on the poor is very important. It is the only tool that service providers, MFIs, donors and governments can use to indicate the effectiveness of their programmes. Funders for instance have therefore continued to experience intense pressure to prove that their investments have really had some impact on the poor and the very poor (Snodgrass, 2002).

Impact assessment can be initiated by different kinds of institutions such as donors, academic institutions, research organizations, individuals and the MFI themselves. Donor funded impact assessments particularly those initiated by CGAP and USAID aims at using quantitative analysis to assess the impact of micro finance on poverty.

A commonly used impact assessment framework is the AIMS Impact Assessment framework which considers the complex interactions existing among individual, household, enterprise and community levels of micro finance programmes. It is therefore suggested that impact assessment in micro finance should be seen as 'learning' rather than 'policing' (Mayoux, 2001).

\section{Impact of Micro Finance on Poverty Reduction}

No mention can be made of micro finance without reference to Bangladesh where it supposedly all began. In fact, Bangladesh has been at the forefront of micro finance "since its inception in the early 1980s and today is home to the most extensive micro finance operations in the world. In Bangladesh and elsewhere around the world, micro finance operations support mainly the poor and women engaged in informal activities" (Quaraishi, 2007). Besides credit, micro finance also offer skill-based training and in so doing empowers the poor (Quaraishi, 2007). Quaraishi (2007) also uses data from studies conducted by the Bangladesh Institute of Development Studies and the World Bank to show that micro finance reduces poverty among poor borrowers and within the local economy, albeit at a lower rate. 
Although micro finance has been acclaimed to reduce poverty and vulnerability to it in some regions of the world, it is estimated that there are still three billion people in the world currently who do not have access to any form of financial services (Helmes, 2006). It is also estimated that there are six hundred and ninety million people in Asia, fifty million people in Bangladesh, ninety million in China, three hundred million people in India, ninety million in Indonesia, fifty two million in Pakistan, twenty seven million in the Philippines and many others in Africa of poor people who do not have access to any form of financial services (Latifee, 2000). Perhaps the harshest criticism of the value of microcredit found in the literature whilst undertaking our study comes from Bateman and Chang (2009) who wrote in their work titled the micro finance illusion:

\begin{abstract}
"In both developing and transition economies, micro finance has increasingly been positioned as one of the most important poverty reduction and local economic and social development policies. Its appeal is based on the widespread assumption that simply 'reaching the poor' with microcredit will automatically establish a sustainable economic and social development trajectory animated by the poor themselves. We reject this view. We argue that while the micro finance model may well generate some positive short run outcomes for a lucky few of the 'entrepreneurial poor', the longer run aggregate development outcome very much remains moot".
\end{abstract}

These authors even went further to suggest that micro finance actually perpetuates poverty. Regardless of one's position on the matter, it is clear from empirical results and criticisms such as those of Bateman and Chang (2009) that micro finance has really not delivered on the promise of alleviating poverty among the poor to a level of comfort talk less of permanent escape from poverty.

In order to reduce poverty to a meaningful level, the gap that currently exist between the rich and the poor needs to be closed. Rutherford, (1996) pointed out that MFIs that wish to have a direct impact on poverty using their services, will have to concentrate on how to make those services useful to the poor in terms of the range of services provided, outreach(depth and breadth), quality and cost of such services.

Many studies have been conducted in Ghana to assess the impact of micro finance activities on the lives of its clients. Notable among these studies are Sinapi Aba Trust (SAT)'s Impact Assessment findings in 2002 and that of Samuel Afrane in 1998 (Atiase, 2008). SAT's own impact studies focussed on assessing the impact of micro finance on the economic, social, spiritual and political aspects of life of clients (Atiase, 2008). In terms of economic impact, the study indicated that $78 \%$ of the matured clients (2 years and above participation) had increases in their business turnover with $98 \%$ of the women clients interviewed claiming that they were now financially independent of their husbands; socially half of SAT's women clients indicated they were empowered in terms of decision making at business, community, household and individual levels of their lives; spiritual wise, $12 \%$ of the clients now perform their business activities more ethically; and politically, the study indicated that majority of SAT's clients have started voting in both local and national elections due to their ability to purchase radio and television sets which enabled them to listen to civic education programmes (Atiase, 2008).

In a similar but independent study conducted by Afrane (1998) on the impact of SAT's micro finance programme on gender, business, access to social facilities, and participation in community activities, the result of the study indicated that SAT's micro finance programme in Ghana have strong positive impact on the businesses and households of the beneficiaries (Atiase, 2008). Moreover, it revealed that the empowerment of women was significant, evidenced from the business turnover of women clients compared to that of men. This has resulted in increased contribution to family income by women and increased involvement of women in social and community activities (Atiase, 2008).

So, while there are encouraging results of positive impact of micro finance on poverty reduction, there is equally worrying evidence of criticism of the ability of micro finance to substantially lessen the poverty problem.

\title{
9. Some Key Problems of Micro Finance Impact Assessment
}

It has proven difficult to measure the actual impact of micro-finance on poverty (Mehdi \& Schwank, 2011). There are many problems that are associated with conducting micro finance impact assessment that truly reveals the outcomes of micro finance services on the beneficiaries.

Firstly, impact assessment projects can be quite expensive considering resource, time, consultants and field interviewers that must be used. Funding of impact studies could therefore be burdensome on MFIs.

The second problem has to do with adopting the right methodology that gets the right information from respondents. Like in all research, some impact studies may not reveal correct outcomes due to respondents giving incorrect data to be processed and respondents not willing to spare their time for an interview.

Sometimes, the poor s are not able to separate their household or personal expenses from their businesses. Loans 
when taken are diverted to pay for other things such as wedding expenses, funeral expenses, school fees and in buying fixed assets (Sharma \& Buchenrieder, 2002). This has made impact assessment difficult since the loans are not used for the intended purposes and therefore any change at the enterprise level cannot be attributed totally to the use of loans.

Another difficulty associated with impact studies is attributing a change in circumstances of the beneficiaries solely to the credit intervention (Johnson \& Rogaly, 1997). In most developing countries there are series of development projects and interventions, all which are aimed at poverty reduction. It is therefore very difficult to solely quantify the impact of a credit programme on poverty reduction.

The current trend of multi borrowing by clients poses another challenge to impact assessment. The abundance of MFIs and other financial intermediaries have made clients to borrow from different sources at the same time. It is therefore difficult to attribute a change in life circumstances of a client solely to a particular credit programme.

In selecting and designing the right approach for an impact assessment in micro finance, Hulme (1997) emphasized that, there are some basic questions such as "what are the objectives of the assessment; how is the information to be used and by whom?; what level of reliability is required; how complex is the programme, and what is already known about it, and what resources are available for the assessment" need to be asked.

\section{Concluding Remarks}

The important role of micro finance in development cannot be over emphasized. It is clear from the literature review that micro finance is indispensable in the achievement of the millennium development goal of poverty reduction, as it puts confidence in the poor to contribute their quota to the economy of their respective countries.

Indeed, micro finance enables the poor to deal with both family and financial shocks whenever they happen. Many impact studies have suggested that most micro finance programmes have at least provided this opportunity to the poor. Thus, micro finance programmes have reduced the vulnerability of the poor.

But it is also clear that micro finance cannot solve all poverty problems and it is not intended to eradicate poverty completely. Rather, it is meant to reduce it. However, providing a comprehensive financial service to the poor demands some level of commitment on the part of governments, micro finance institutions, donors and other financial institutions.

Targeting enables an MFI to reach out to certain categories of people who might currently be excluded due to poor targeting on the part of the MFI. Targeting strategies such as Cashpor Housing Index, Participatory Rural assessment, Interviews and surveys could be a way of identifying those who truly need micro finance services and also to prevent those services getting into the hands of the non-poor.

Micro finance impact assessment can provide the right information about the effectiveness of financial services that are provided to the poor. MFIs constantly need to assess their level of outreach both in scale and in depth in order to observe whether the expected transformation is taking place in the life of their clients. If such acclaimed transformation cannot be evidenced through a rigorous impact studies in the lives of clients, then the MFI has to reconsider its portfolio mix and mission.

In developing countries, such as Ghana, where patriarchy is entrenched into the social system, access to financial resources could empower women to contribute their quota to the development of the household and the country as a whole. This could be a way of bridging the gender gap that currently exists.

\section{References}

Afrane, S. (2002). Impact Assessment of Microfinance Interventions in Ghana and South Africa. Journal of Microfinance. 4(1):37-58.

Aguilar, G. (2006). Is Micro-Finance reaching the Poor? An Overview of Poverty Targeting Methods. Available at: http://www.globenet.org/archives/web/2006/www.globenet.org/horizon-local/ada/c18.html. Accessed on 26/6/2008.

Asian Development Bank (ADB). (2000). Finance for the Poor: Microfinance Development Strategy. Available at: http://www.adb.org/Documents/Policies/Microfinance/financepolicy.pdf. Accessed on 8/12/2007.

Atiase, VY. 2008. Commercialization of Microfinance; Promising or Perilous to the Poor?-A Case Study of Ghanaian Microfinance Institutions. Unpublished Masters Dissertation. University of Bath.

Bakhoum, I. et al. (1989). Banking the Unbankable. London: Panos Publications Limited.

Bateman, M, \& Chang, H.J. (2009). The Microfinance Illusion. Available at: http://www.mic_rofinancetransparency.com/evidence/PDF IApp.3\%20Chang\%20Bateman\%20article.pdf. Accessed on 07/07/2014.

Brau, C. \& Woller, M. (2004). Microfinance: A comprehensive Review of the Existing Literature. Journal of Entrepreneurial Practice and Business Venture. 9(1):1-26.

Cheston, S. \& Kuhn, L. (2002). Empowering Women through Microfinance. Available at: http://www.opportunity.org.uk/resources/file/ EmpoweringWomenPaperFINAL.pdf. Accessed on 30/06/2008. 
Cohen, M. \& Sebstad, J. (1999). Microfinance Impact Evaluation: Going Down Market. Available at: http://www.rrojasdatabank. org/wpover/evalfin1.pdf. Accessed on 25/06/2008.

Copestake, J, Greely, M, Johnson, S, Kabeer, N, \& Simanowitz, A. (2005). Money with a Mission. Vol. 1. Warwickshire: Institute of Development Studies.

Fernando, L. (2006). Microcredit and Empowerment of Women: Blurring the boundary between Development and Capitalism. In L. Fernando (Ed.), Microfinance: Perils and Prospects (pp. 1-2). Abingdon: Routledge.

Fischer, S. 2005. The Hidden Wealth of the Poor. Economist. 377(8451):3-6.

Harper, M, \& Arora, S.S. (2005). Small Customers, Big Markets: Commercial Banks in Microfinance. Warwickshire: ITDG Publishing.

Helmes, B. (2006). Access for all: Building Inclusive Financial Systems. Washington: The International Bank for Reconstruction and Development.

Hulme, D. (1997). Impact Assessment Methodologies for Microfinance: A review. Available at: http://www.microfinancegateway.org/ content/article/detail/1226 Accessed on 25/06/2008.

Hume, D, \& Mosley, P. (1996). Finance against Poverty. Vol. 1. London: Routledge.

Johnson, S, \& Rogaly, B. (1997). Microfinance and Poverty Reduction. Oxford: Oxfam.

Krishna, A. (2003). Social Capital, Community Driven Development and Empowerment: A Short note on Concepts and Operations. Available at: http://siteresources.worldbank.org/INTEMPOWERMENT/Resources/486312-1097679640919/think_pieces krishna. pdf. Accessed on 30/06/2008.

Latifee, H.I. (2000). Microfinance and Poverty Reduction: Experiences of Grameen Operations in Asia. Available at: http://www.microfinancegateway.org/content/article/detail/3502. Accessed on 21/05/2008.

Littlefield, E, Morduch, J, \& Hashemi, S. (2003). Is Microfinance an Effective Strategy to Reach the Millennium, Development Goals? Available at: http://ifmr.ac.in/cmf/wp-content/uploads/2007/06/mf-mdgs-morduch.pdf. Accessed on 30/05/2008.

Mayoux, L. (2000). Micro-finance and the Empowerment of Women: A Review of the Key Issues. Available at: http://www.microfinancegateway.org/files/2842_file_02842.pdf. Accessed on 29/06/2008.

Mayoux, L. (2001). Impact Assessment of Microfinance: Towards a Sustainable Learning Process. Available at: http://www.enterpriseimpact.org.uk/pdf/Microfinance.pdf. Accessed on 25/06/2008.

Mehdi, D. and Schwank, O. 2011. Microfinance: What role in Africa's development? Available at: http://www.un.org/africarenewal/ magazine/august-2011/microfinance-what-role-africas-development. Accessed on 07/06/2014.

Morduch, J. (2000). The Microfinance Schism. World Development. 28(4):617-629.

Morduch, J. (1999). The Microfinance Promise. Journal of Economic Literature. 37(4):1569-1614

Quaraishi, S. 2007. How empowering is microcredit: a look at Grameen bank. Available at: http://www.google.co.za/url?sa= \&rct= $j \& q=\& e s r c=s \&$ source=web\&cd=9\&ved=0CGoQFjAl\&url=http\%3A\%2F\%2Fwww.usbig.net\%2Fpapers\%2F173-QuaraishiGrameenBank.doc\&ei=MtORU-

v9Eaje7Abcr4GwCw\&usg=AFQjCNHEdw_H6YKem2GcSazqWmxSe78mUw\&sig2=oiGUCc5GE9cazd7jSIGzQw. Accessed on 06/06/2014.

Rutherford, S. (1996). A Critical Typology of Financial Services. Available at: http://www.microfinancegateway.org/content/article /detail/1845\%20. Accessed on 24/05/2008.

Schneider, H. (1997). Microfinance for the Poor. Paris, France: IFAD/Organization for Economic Co-operation and Development.

Sharma, M, \& Buchenrieder, G. (2002). Impact of Microfinance on Food Security and Poverty Alleviation: A Review and Synthesis of Empirical Evidence. In M. Zeller, \& L. Meyer (Eds.). The Triangle of Microfinance: Financial Sustainability, Outreach and Impact (pp. 222-223). Baltimore: John Hopkins University.

Snodgrass, R. (2002). Clients in Context: The Impacts of Microfinance in Three Countries-A synthesis Report. Washington D.C: USAID.

Vanroose, A \& D'espallier, B. 2009. Microfinance and Financial Sector Development. Centre Emile Berheim Research Institute in Management Science working paper series No. 09/040. September 2009. Available at: http://www.microfinancegateway.org/gm/ document-1.9.40607/09.pdf. Accessed on 06/06/2014.

World Bank. (2001). Engendering Development: Through Gender Equality in Rights, Resources and Voice. Available at: http://info.worldbank.org/etools/docs/library/76309/dc2002/proceedings/pdfpaper/module7ekam.pdf. Accessed on 30/06/2008. 
